IISSN: 2224-0616

Int. J. Agril. Res. Innov. \& Tech. 2 (1): 56-61, J une, 2012

Available online at http:// www.ijarit.webs.com

\title{
ABUNDANCE OF PLANKTON POPULATION DENSITIES IN RELATION TO BOTTOM SOIL TEXTURAL TYPES IN AQUACULTURE PONDS
}

\author{
F. Siddika, M. Shahjahan* and M.S. Rahman \\ Received 8 March 2012, Revised 7 June 2012, Accepted 15 June 2012, Published online 30 June 2012
}

\begin{abstract}
Plankton is an important food item of fishes and indicator for the productivity of a water body. The present study was conducted to evaluate the effects of bottom soil textural conditions on abundance of plankton in aquaculture pond. The experiment was carried out using three treatments, i.e., ponds bottom with sandy loam (T1), with loam (T2) and with clay loam (T3). The ranges of water quality parameters analyzed were suitable for the growth of plankton during the experimental period. Similarly, chemical properties of soil were also within suitable ranges and every parameter showed higher ranges in T2. A total 20 genera of phytoplankton were recorded belonged to Chlorophyceae (7), Cyanophyceae (5), Bacillariophyceae (5), Euglenophyceae (2) and Dinophyceae (1). On the other hand, total 13 genera of zooplankton were recorded belonged to Crustacea (7) and Rotifera (6). The highest ranges of phytoplankton and zooplankton densities were found in T2 where low to mediumtype bloom was observed during the study period. Consequently, the mean abundance of plankton (phytoplankton and zooplankton) density was significantly highest in T2. The highest abundance of plankton in the T2 indicated that pond bottom with loamy soil is suitable for the growth and production of plankton in aquaculture ponds.
\end{abstract}

Keywords: Phytoplankton, zooplankton, aquaculture, soil textural classes, water quality

Department of Fisheries Management, Bangladesh Agricultural University, Mymensingh-2202, Bangladesh.

*Corresponding author's email: shahjahanm75@yahoo.co.uk (M. Shahjahan)

Reviewed by Abdullah-Al Mamun, Noakhali Science and Technology University, Bangladesh

\section{Introduction}

Live organisms of the water consists of three major groups namely plankton, nekton and benthos. Among these, plankton is of fundamental importance to fisheries. Plankton is also a vital factor influencing the fish production. Phytoplankton is the basic primary producers of all types of water bodies and is used as food by fish directly or indirectly. The qualitative and quantitative abundance of phytoplankton indicate the productive status of a water body, whether it is an oligotrophic or a eutrophic one. Therefore, a thorough knowledge of abundance of phytoplankton and its quality in time and space in relation to environmental conditions has become a prerequisite for fish production. Existence of zooplankton production primarily depends on the primary production. Zooplankton is a link in food chain between the primary producers and nektonic and benthonic animals in higher trophic levels. Their functions decrease phytoplankton populations through grazing (Raymont, 1963); accelerate phytoplankton growth excreting nutrient substances which are finally metabolized (Ketchum, 1962); and supply themselves as food to predators.
The nutrients status of both soil and water plays a significant role in the growth and abundance of aquatic organisms, especially plankton and benthos. The chemical properties (nutrients status) have some growth promoting effect on the various species of benthos fauna (Habib et al., 1984). On the other hand, nutrient status of soil depends on the type of soil texture. In soil science, the USDA (Donahue et al., 1990) defines twelve major soil textural classes. Soil textures are classified by the fractions of each soil separate (sand, silt, and clay) present in a soil. Classifications are typically named for the primary constituent particle size or a combination of the most abundant particles sizes, e.g. sandy clay or silty clay. A fourth term, loam, is used to describe a roughly equal concentration of sand, silt, and clay, and lends to the naming of even more classifications, e.g. clay loam or silty loam or sandy loam. Loam soils generally contain more nutrients and humus than sandy soils. However, so far there is no study on the effects of bottom soil textural conditions on growth and abundance of benthic fauna. Productivity of plankton and productivity of water body depends on the kind of textural class of pond bottom-soil. In the present study, 
an experiment was conducted to evaluate the effects of bottom soil textural conditions on abundance of plankton in aquaculture ponds.

\section{Materials and Methods}

\section{Experimental design}

The experiment was conducted in the ponds situated at the campus of Bangladesh Agricultural University, Mymensingh during August to November 2011. The experiment had three treatments with three replications, i.e., ponds bottom with sandy loam (T1), with loam (T2) and with clay loam (T3). The average depth of the experimental ponds was $106.68 \mathrm{~cm}$.

\section{Water quality parameters}

Various physical and chemical water quality parameters of the ponds such as water temperature $\left({ }^{\circ} \mathrm{C}\right)$, transparency $(\mathrm{cm})$, dissolved oxygen (mg L-1), $\mathrm{pH}$, free $\mathrm{CO}_{2}\left(\mathrm{mg} \mathrm{L}^{-1}\right)$, total alkalinity $\left(\mathrm{mg} \mathrm{L}^{-1}\right), \mathrm{PO}_{4}-\mathrm{P}\left(\mathrm{mg} \mathrm{L}^{-1}\right)$ and $\mathrm{NO}_{3}-\mathrm{N}(\mathrm{mg}$ $\mathrm{L}^{-1}$ ) were estimated fortnightly following the standard method.

\section{Chemical parameters of pond bottom-soil (sediment)}

Various chemical parameters of the ponds bottom soil (sediment) such as $\mathrm{pH}$, available phosphorus (ppm), total nitrogen (\%), organic carbon (\%) and organic matter (\%) were estimated fortnightly using standard method (Sattar and Rahman, 1987).

\section{Study of plankton}

Plankton population of ponds water such as phytoplankton density (cells $\mathrm{L}^{-1}$ ) and zooplankton density (cells $\mathrm{L}^{-1}$ ) were estimated fortnightly. The counting of plankton (both phytoplankton and zooplankton) was done with the help of SedgwickRafter Counting Cell (S-R cell) under a compound binocular microscope. The plankton population was determined by using the formula of Rahman, (1992). Identification of plankton (phytoplankton and zooplankton) up to generic level were made according to Prescott (1964), Needham and Needham (1963) and Belcher and Swale (1978).

\section{Statistical analysis}

Values are expressed as means \pm standard error of the mean (SEM). Data were analyzed by oneway analysis of variance (ANOVA) followed by Tukey's post hoc test to assess statistically significant differences among the different sampling days and different treatments. Statistical significance was set at $\mathrm{P}<0.05$. Statistical analyses were performed using SPSS Version 14.0 for Windows (SPSS Inc., Chicago, IL).

\section{Results and Discussion}

The present study was conducted to evaluate the effects of bottom soil textural conditions on the abundance of plankton in aquaculture ponds. The highest abundance of plankton found in the ponds bottom with loam indicated that loamy bottom soil is suitable for the growth and production of plankton in aquaculture ponds.

\section{Water quality and bottom-soil (sediment) parameters of ponds}

The water quality parameters of the experimental ponds were within the productive ranges for the growth of plankton and benthos and showed no abrupt changes during the tenure of experiment (Table 1). Within limit productive ranges of such water quality parameters have also observed by a number of other authors (Wahab et al., 1995; Kohinoor et al., 1998; Haque et al., 1998; Uddin et al., 2007; Chowdhury et al., 2008). Similarly, the ranges of $\mathrm{pH}$, organic carbon (\%), organic matter (\%), available phosphorus (ppm) and total nitrogen (\%) of pond bottom-soil in the aquaculture ponds were within the suitable ranges and showed no abrupt changes during the experimental period in all the treatments (Table 2). These results is in agreement with Akter (2006), who observed more or less similar results during his study on effect of bottom soil properties on the abundance of benthic fauna in nursery ponds.

Table 1. Water quality parameters (Means \pm SEM; $n=3$ ) of the ponds during the experimental periods

\begin{tabular}{lrrr}
\hline Parameters & & Treatments & \\
\cline { 2 - 4 } & Treatment 1 & Treatment 2 & Treatment 3 \\
\hline Water temperature $\left({ }^{0} \mathrm{C}\right)$ & $27.20 \pm 3.13$ & $27.00 \pm 3.07$ & $27.20 \pm 3.20$ \\
Air temperature $\left({ }^{\circ} \mathrm{C}\right)$ & $27.50 \pm 2.88$ & $27.50 \pm 2.88$ & $27.50 \pm 2.88$ \\
Transparency (cm) & $32.30 \pm 0.91^{*}$ & $16.00 \pm 1.15$ & $15.30 \pm 1.11$ \\
Dissolved oxygen $\left(\mathrm{mgL}^{-1}\right)$ & $7.86 \pm 0.24$ & $7.21 \pm 0.70$ & $5.86 \pm 0.48$ \\
Free $\mathrm{CO}_{2}\left(\right.$ mgL-1) $\left.^{-1}\right)$ & $3.86 \pm 0.90$ & $3.43 \pm 1.62$ & $4.00 \pm 0.82$ \\
Total alkalinity (mgL-1) & $82.72 \pm 8.28$ & $149.14 \pm 9.05^{*}$ & $51.00 \pm 6.86$ \\
Phosphate-phosphorous (mgL-1) & $2.20 \pm 0.58$ & $2.68 \pm 0.23$ & $1.73 \pm 0.46$ \\
Nitrate-nitrogen (mgL-1) & $3.11 \pm 0.55$ & $3.58 \pm 0.19$ & $2.78 \pm 0.33$ \\
* indicates the significant difference among the treatment & & &
\end{tabular}


Table 2. Chemical parameters of pond bottom-soil (means \pm SEM; $n=3$ ) during the experimental periods

\begin{tabular}{lrrr}
\hline Parameters & \multicolumn{3}{c}{ Treatments } \\
\cline { 2 - 4 } & Treatment 1 & Treatment 2 & Treatment 3 \\
\hline pH & $7.03 \pm 0.13$ & $7.13 \pm 0.16$ & $7.32 \pm 0.13$ \\
Organic carbon (\%) & $0.78 \pm 0.03$ & $0.94 \pm 0.02$ & $0.84 \pm 0.03$ \\
Organic matter (\%) & $1.36 \pm 0.01$ & $1.64 \pm 0.01$ & $1.41 \pm 0.01$ \\
Available phosphorus (ppm) & $13.86 \pm 0.51$ & $25.76 \pm 0.13$ & $16.99 \pm 0.38$ \\
Total nitrogen (\%) & $0.073 \pm 0.005$ & $0.076 \pm 0.005$ & $0.08 \pm 0.01$ \\
\hline
\end{tabular}

\section{Abundance of plankton}

A total 20 genera of phytoplankton (Table 3) were recorded belonged to Chlorophyceae (7), Cyanophyceae (5), Bacillariophyceae (5), Euglenophyceae (2) and Dinophyceae (1) were recorded in the present study, which is more or less similar to the findings with Kohinoor, (2000) who recorded 24 genera of phytoplankton belonging to Euglenophyceae,
Cyanophyceae, Bacillariophyceae and Chlorophyceae. More or less similar numbers of genera were recorded in the plankton population by a number of authors in the ponds of Bangladesh Agricultural University campus (Dewan et al., 1991; Wahab et al., 1995; Kohinoor et al., 1998; Uddin et al., 2007 and Chowdhury et al., 2008).

Table 3. Generic status of phytoplankton under different major groups found in the aquaculture ponds during the experimental periods

\begin{tabular}{llll}
\hline \multirow{2}{*}{ Major groups } & \multicolumn{1}{c}{ Generic names } & \\
\cline { 2 - 4 } Chlorophyceae & T1 & T2 & T3 \\
& Oocystis & Chlorella & Chlorella \\
& Pediastrum. & Pediastrum & Oocystis \\
& Scenedesmus & Scenedesmus & Pediastrum \\
& Ulothrix & Closterium & Scenedesmus \\
& & Actinastrum & Closterium \\
Cyanophyceae & Anabaena & Oocystis & Microcystis. \\
& Gomphospaeria & Microcystis & Anabaena \\
& Microcystis & Anabaena & Gomphospaeria \\
& & Gomphospaeria. & Oscillatoria \\
Bacillariophyceae & Cyclotella & Aphanocapsa & \\
& Diatoma & Oscillatoria & Asterionella \\
& Asterionella & Asterionella & Cyclotella \\
& & Cyclotella & Diatoma \\
& & Diatoma & Fragillaria \\
Euglenophyceae & Euglena & Fragillaria & Tabellaria. \\
& Phacus & Tabellaria. & Euglena \\
Dinophyceae & Ceratium & Euglena & Phacus \\
\hline
\end{tabular}

Table 4. Fortnightly variations in mean abundance of total phytoplankton (x105 cells $\left.\mathrm{L}^{-1}\right)$ in the experimental ponds under three treatments during the study period.

\begin{tabular}{|c|c|c|c|c|c|c|c|}
\hline \multirow[t]{2}{*}{ Treatments } & \multicolumn{7}{|c|}{ Sampling days } \\
\hline & 1 & 2 & 3 & 4 & 5 & 6 & 7 \\
\hline $\mathrm{T} 1$ & 9.07 & 9.16 & 8.30 & 7.85 & 8.00 & 9.40 & 10.24 \\
\hline $\mathrm{T} 2$ & 30.05 & 32.90 & 29.70 & 29.39 & 29.70 & 32.72 & 32.30 \\
\hline T3 & 19.00 & 16.90 & 15.80 & 19.50 & 15.80 & 21.10 & 19.10 \\
\hline
\end{tabular}

The densities of phytoplankton (means \pm SEM; $\mathrm{n}=3$ ) were ranged from 7.85 to $10.24,29.39$ to 32.90 and 15.80 to 21.10 (x 105) cells $\mathrm{L}^{-1}$ in the ponds of T1, T2 and T3, respectively (Table 4). Phytoplankton abundance in aquaculture ponds were recorded in some other studies ranged from 2.0 - $8.0 \times 10^{5}$ cells $\mathrm{L}^{-1}$ (Dewan et al., 1991), 9.26 - $16.03 \times 10^{4}$ cells $\mathrm{L}^{-1}$ (Wahab et al., 1991) and $10.70-50.65 \times 10^{4}$ cells L $^{-1}$ (Haque et al., 1998). The mean abundance of total 
phytoplankton (Fig. 1) was significantly higher in T2 followed by T3 and T1 where light to mediumtype bloom was observed during the study period.

(1991), Chowdhury and Sultana (1989) in various Similar observations were noted by Mathias

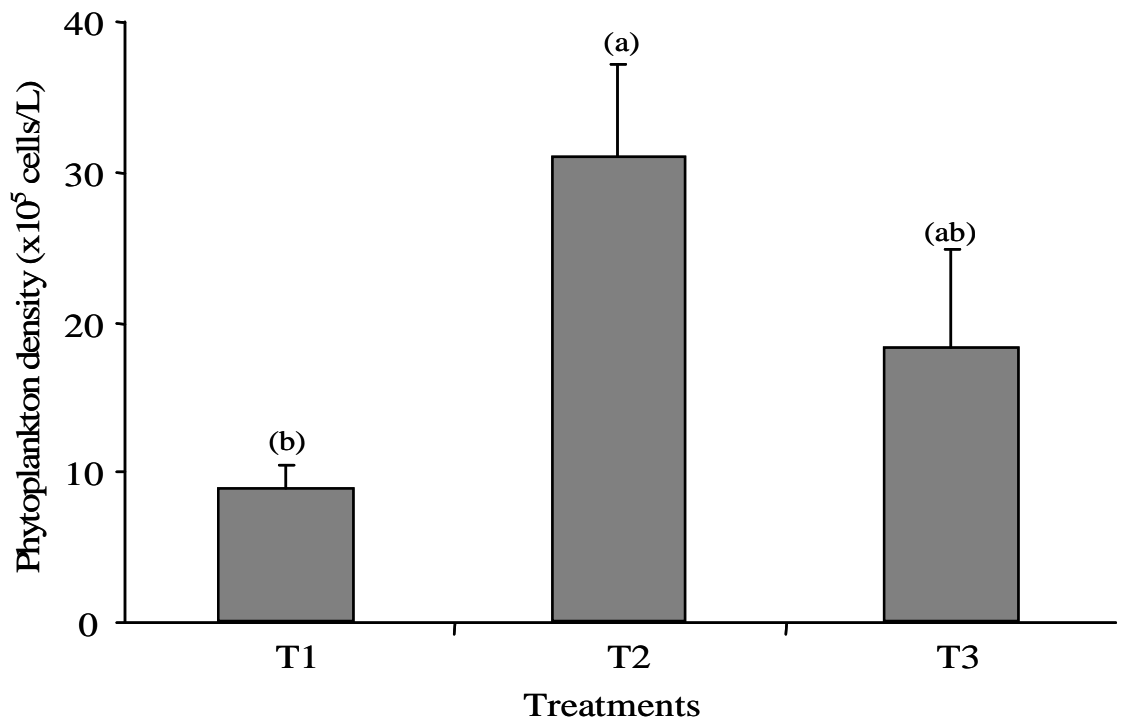

Fig. 1. Cell densities (means $\pm \mathrm{SEM} ; \mathrm{n}=3$ ) of total phytoplankton in different treatments during the study period. Values accompanied by different letters are statistically significantly different $(\mathrm{p}<0.01)$.

Total 13 genera of zooplankton (Table 5) were recorded belongs to Crustacea (7) and Rotifera (6). Kiran et al. (2007) found in their study that the population of zooplankton consisted of cladocerans (4), copepods (2) and rotifers (7),

which are more or less similar to the present study. Masud et al. (1996) recorded 11 genera of zooplankton belonging to crustacean (7) and rotifera (4) which are lower than those of the present study.

Table 5. Generic status of zooplankton under different major groups found in the aquaculture ponds during the experimental periods

\begin{tabular}{|c|c|c|c|c|}
\hline \multirow{2}{*}{\multicolumn{2}{|c|}{ Major groups }} & \multicolumn{3}{|c|}{ Generic names } \\
\hline & & T1 & T2 & T3 \\
\hline \multirow{6}{*}{ Crustacea } & Cladocera & Daphnia & Daphnia & Daphnia \\
\hline & & Diaphanosoma & Diaphanosoma & Diaphanosoma \\
\hline & & Ceriodaphnia & Ceriodaphnia & Ceriodaphnia \\
\hline & & & Moina & Moina \\
\hline & Copepoda & Cyclops & Cyclops & Cyclops \\
\hline & & Diaptomus & Diaptomus & Diaptomus \\
\hline \multirow{7}{*}{ Rotifera } & Crustacean larva & Nauplius & Nauplius & Nauplius \\
\hline & & Brachionus & Asplanchna & Asplanchna \\
\hline & & Filinia & Brachionus & Brachionus \\
\hline & & Keratella & Filinia & Filinia \\
\hline & & Hexarthra & Keratella & Keratella \\
\hline & & Polyarthra. & Hexarthra & Hexarthra \\
\hline & & & Polyarthra & Polyarthra \\
\hline
\end{tabular}

Table 6. Fortnightly variations in mean abundance of total zooplankton (x103 cells $\mathrm{L}^{-1}$ ) in the experimental ponds under three treatments during the study period.

\begin{tabular}{llllllll}
\hline Treatments & \multicolumn{7}{c}{ Sampling days } \\
\cline { 2 - 8 } & 1 & 2 & 3 & 4 & 5 & 6 & 7 \\
\hline T1 & 25.00 & 25.40 & 25.50 & 24.10 & 22.70 & 22.70 & 26.50 \\
T2 & 78.50 & 81.30 & 84.10 & 86.30 & 74.40 & 83.40 & 93.80 \\
T3 & 66.90 & 61.00 & 67.00 & 67.90 & 60.40 & 55.90 & 76.00 \\
\hline
\end{tabular}


The densities of zooplankton (means \pm SEM; $\mathrm{n}=$ 3) were ranged from $22.7 \pm 2.32$ to $26.50 \pm$ $3.32,74.40 \pm 3.50$ to $93.8 \pm 4.56$ and $55.90 \pm$ 3.65 to $76.00 \pm 3.85$ ( $\mathrm{x} \mathrm{10} 0^{3}$ ) cells $\mathrm{L}^{-1}$ in the ponds of T1, T2 and T3, respectively (Table 6). The mean abundance of total zooplankton (Fig. 2) was significantly higher in T2 followed by T3 and T1. Dewan et al. (1991) found zooplankton density ranged between $2.0 \times 10^{5}$ cells $\mathrm{L}^{-1}$ and 2.0 $\times 10^{5}$ cells $\mathrm{L}^{-1}$ which are more or less similar to that of the present study.

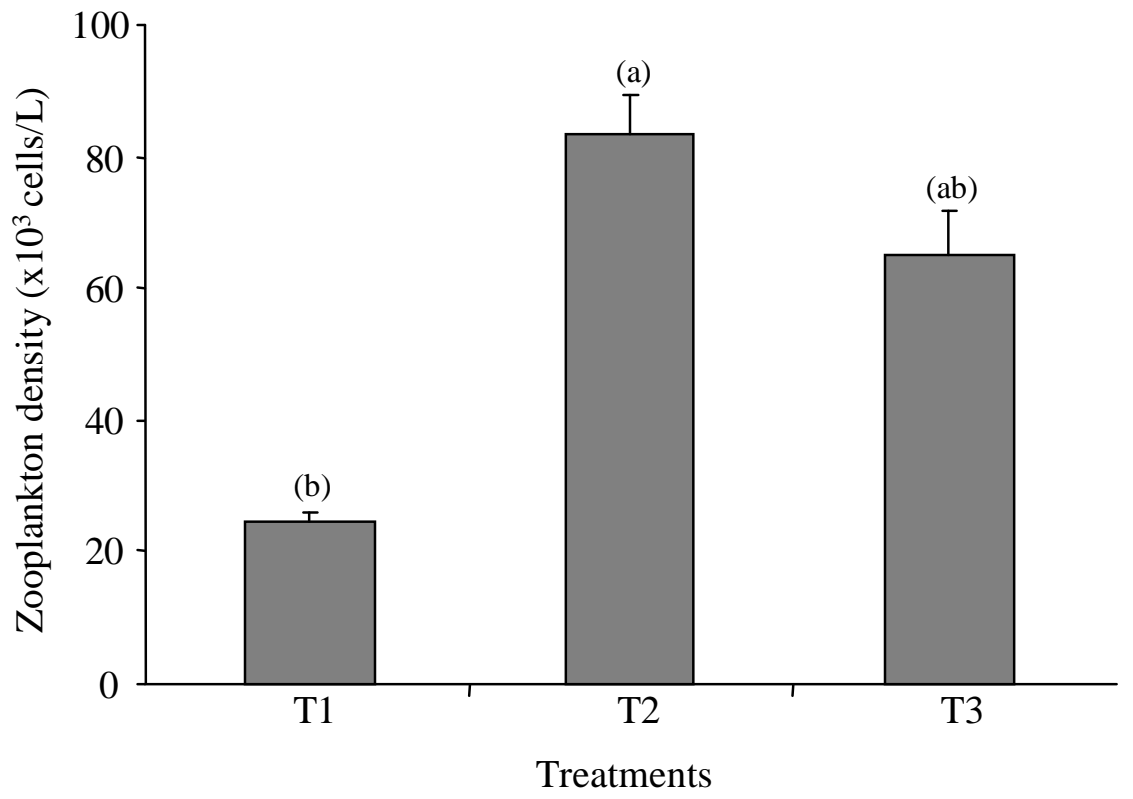

Fig. 2. Cell densities (means $\pm \mathrm{SEM} ; \mathrm{n}=3$ ) of total zooplankton in different treatments during the study period. Values accompanied by different letters are statistically significantly different $(\mathrm{p}<0.01)$.

However, in the present study, significantly highest mean abundance of phytoplankton and zooplankton were recorded in T2 (Fig. $1 \& 2$ ). The occurrence of these groups of plankton might be due to the suitable ecological conditions of the ponds that favoured the growth of these groups. Hulyal and Kaliwal (2008) found in an experiment that the distribution and population density of zooplankton depends upon the physicochemical factors of the environment. On the other hand, chemical properties of soil were comparatively higher in T2 (Table 2) may be an important cause to the higher abundance of macro-benthos population in the present study. This argument also supported by Ali et al. (1987), Verneax et al. (2004) and Kailasam and Sivakami (2004) who found the significant effect of chemical properties on the plankton growth and production. Moreover, loam soils generally contain more nutrients and humus. Humus is a temporary intermediate product left after considerable decomposition of dead plants and animals, which might be support food for macrobenthos. This result indicated that pond bottom with loamy soil is suitable for growth and production of macro-benthos in aquaculture ponds.
In conclusion, suitability of bottom soil textural conditions on abundance of plankton population density was analyzed in aquaculture ponds. Most of the water quality parameters of the ponds were more or less similar and within productive limit, and chemical properties of soil were also within suitable ranges. The mean abundance of plankton density was significantly highest in T2 indicated that loamy soil bottom is suitable for the growth and production of plankton in aquaculture ponds.

\section{References}

Akter, N. 2006. Effect of bottom soil properties on the abundance of benthic fauna in nursery ponds. MS thesis, Department of Aquaculture, Bangladesh Agricultural University, Mymensingh, Bangladesh. p. 74.

Ali, M.M., Rahmatullah, S.M. and Habib, M.A.B. 1987. Abundance of benthic fauna in relation to metrological and physicalchemical factors of water. Bangladesh J. Agril. Sci., 12: 239-247.

Belcher, H. and Swale E. 1978. A Beginner's Guide to Freshwater Algae. HMSO, London. p. 47.

Chowdhury, A.N.B. and Sutltana, N. 1989. Occurrence and seasonal variation of 
zooplankton in a fish pond in relation to some physicochemical factors. Bangladesh J . Zool., 17: 101-106.

Chowdhury, M.M.R., Shahjahan M., Rahman, M.S. and Sadiqul Islam M. 2008. Duckweed (Lemna minor) as supplementary feed in monoculture of nile tilapia, Oreochromis niloticus. J. Fish. and Aquatic Sci., 3: 54-59.

Dewan, S., Wahab, M.A., Beveridge, M.C.M., Rahman, M.H. and Sarker, B.K. 1991. Food selection, electivity and dietary overlap among planktivorous Chinese and Indian Major Carps fingerlings grown in extensively managed, rain-fed ponds in Bangladesh. J. Aqua. and Fish. Manag., 22: 277-294.

Donahue, R.L., Miller, R.W. and Shickluna, J.C. 1990. Soils-An Introduction to Soils and Plant Growth. Prentice-Hall of India Private Ltd, New Delhi. 110001.667p.

Habib, M.A.B., Haque, A.K.M. and Islam M.A. 1984. Status of macro-benthos in two ponds in Bangladesh Agricultural University Campus, Mymensingh. Bangladesh J . Agril. Sci., 11: 39-46.

Haque, M.S., Wahab, M.A., Wahid, M.I. and Haq, M.S. 1998. Impacts of Thai silver barb (Puntius gonionotus Bleeker) inclusion in the polyculture of carps. Bangladesh J. Fish. Res., 2: 15-22.

Hulyal, S.B. and Kaliwal, B.B. 2008. Water quality assessment of Almatti Reservoir of Bijapur (Karnataka State, India) with special reference to zooplankton. Environment Monitoring Assessment, 139 (1): 299-306.

Kailasam, M. and Sivakami, S. 2004. Effect of thermal effluent discharge on benthic fauna of Tuticorin Bay, South East coast of India. Indian J. Marine Sci., 33: 194-201.

Ketchum, C. 1962. On the study of primary produce in the sea by soviet scientist. Int. Rev. Gel. Hydrobiol, 45: 107-111.

Kiran, B.R., Puttaia, E.T. and Devidas-Kamath. 2007. Diversity and seasonal fluctuation of zooplankton in fish pond of Bhadra fish farm, Karnataka. Zoos Print J ournal, 22(12): 2935-2936.

Kohinoor, A.H.M. 2000. Development of culture technology of three small indigenous fish mola (Amblypharyngodon mola), punti (Puntius sophare) and chela (Chela cucius) with notes on some aspects of their biology. Ph.D. Thesis, Department of Fisheries Management, BAU, Mymensingh. $263 \mathrm{p}$.

Kohinoor, A.H.M., Islam, M.L., Wahab, M.A. and Thilsted, S.H. 1998. Effect of mola
(Amblypharyngodon mola Ham.) on the growth and production of carps in polyculture. Bangldesh J. Fish. Res., 2: 119126.

Masud, A.K.M.S., Chowdhury, H.A., Rahmatullah, S.M., Salam, M.A. and Islam, A.K.M.S. 1996. Comparative study on the zooplankton population of Derelict, Extensive and Semi-intensive Fish Ponds. Bangladesh J. Aquaculture, 18: 33-37.

Mathias, P.M. 1991. Seasonal trends in the fluctuation of phytoplankton and physicochemical factors in a tropical lake (Govindgarh lake, Maddhya Pradesh, India) and their interrelationship. Indian J. Inland Fish. Soc., 17(1-2): 11-24.

Needham, J.G. and Needham, P.R. 1963. A Guide to Study of Freshwater Biology. 5th Edn., Holden-Day, Inc., San Francisco. 106 p.

Prescott, G.W. 1964. Algae of Western Great Lakes area. Wm. C. Brown Co. Dubuque, IOWA, $946 \mathrm{p}$.

Rahman, M.S. 1992. Water Quality Management: Aquaculture. BRAC Prokashana, Mohakhali, Dhaka, Bangladesh. 84p.

Raymont, J.E.G. 1963. Plankton and productivity in the oceans. Macmillan, New York, USA. $60 \mathrm{p}$.

Sattar, M.A. and Rahman, M.M. 1987. Techniques of Soil Analysis, Published by A. Sattar, BAU, Mymensingh. 54 p.

Uddin, M.N., Rahman, M.S. and Shahjahan M. 2007. Effects of duckweed (Lemna minor) as supplementary feed on monoculture of GIFT strain of tilapia (Oreochromis niloticus). Progres. Agric., 18: 183-188.

Verneaux, V., Verneaux, J., Schmitt, A. and Lambert, J.C. 2004. Relationships of macrobenthos with dissolved oxygen and organic matter at the sediment-water interface in Ten French Lakes. Archiv-furHydrobiologie, 160(2): 247-259.

Wahab, M.A., Ahmed, Z.F., Islam, M.A. and Rahmatullah, S.M. 1995. Effect of introduction of common carp, Cyprinus carpio (L.) on the pond ecology and growth of fish in polyculture. Aquaculture Research, 26: 619-628.

Wahab, M.A., Begum, M.A. and Ahmed, ZF. 1991. The effects of silver carp introduction in the polyculture of major Indian carps. BAURes Progrssive, 5: 429-437. 